\title{
Chronic Myelomonocytic Leukemia with Eosinophilia
}

National Cancer Institute

\section{Source}

National Cancer Institute. Chronic Myelomonocytic Leukemia with Eosinophilia. NCI

Thesaurus. Code C36060.

A chronic myelomonocytic leukemia characterized by a peripheral blood eosinophil count of equal or greater than $1.5 \times 10 \mathrm{E} 9 / \mathrm{L}$, and absence of PDGFRA or PDGFRB gene abnormalities. 